\title{
J. Alison Rosenblitt, Rome after Sulla, Bloomsbury Publishing (Bloomsbury Academic), London-New York-Oxford-New Delhi-Sydney 2019, 220 pp., ISBN 978-1-4725-8057-3
}

The analysis of the political situation in the Roman Republic at the end of dictator L. Cornelius Sulla's rule (80-78 BCE) and after his death in the first half of the 70's $\mathrm{BCE}$ is a challenge to the contemporary researchers investigating the decline of the Republic due to a rather unclear image of this historical period in the preserved sources. Sulla's role in Rome and the offices held by him in his last period of life, as well as competition among the politicians being his potential successors and their attitude to the changes to the state introduced by the dictator, are an object of academic discussions among the historians and philologists. In fact, this period significantly affected the political events and the legal and systemic situation of Rome in the last phase of the Republic, starting from the speech by M. Aemilius Lepidus (the so-called tumultus Lepidi) in $78 \mathrm{BCE}$, and ending with the measures taken by C. Julius Caesar, or even Octavian Augustus.

An analysis of this interesting period was undertaken by J. Alison Rosenblitt in her book Rome after Sulla published recently. The author is a Senior College Lecturer in Ancient History at Regent's Park College, University of Oxford, and the Director of Studies in Classics and Ancient History at the University of Oxford. The topics investigated by the author have already been presented in many articles published in several journals (Arethusa, American Journal of Philology, Greece \& Rome etc.), while this work is an extended collection of prior publications.

The book has been divided into three parts, and further into chapters and subchapters. Part One, "Negotiating the End of Sulla," includes two chapters. Here, the author discusses the political situation in Rome in $80 \mathrm{BCE}$, at the decline of Sulla's rule, attempting to draw the image based on the analysis of the M. Tullius Cicero's oration pro Roscio. Despite the fact that the written version was probably noted long after its delivery in $80 \mathrm{BCE}$, and is an amended version of Cicero's speech in the defence of Sextus Roscius Amerinus from Ameria, it was a disguised criticism of the system created by the dictator, which helped many of his advocates of dubious morality gather significant influence and considerable properties. At the same time, the author attempts to reconstruct the last period of Sulla's rule before he withdrew from active politics, trying to determine what function he held at the time. Next, J. A. Rosenblitt presents the political atmosphere in Rome after Sulla's withdrawal from active politics, showing that, despite the prevailing sense of fear in the City, Sulla's dictatorial measures aimed at introducing a stable political system (certainly without the opposition from the populares, depleted as a result of the civil war of 83-82 BCE, proscriptions, and limited by his legislation) did not succeed. 
Part Two, "Counter-revolution," comprises three chapters. Here, J. A. Rosenblitt presents the political situation after the dictator's death. For this purpose, she confronts the existing reports by ancient authors (Cicero, Sallustius, the Livian tradition: e.g. Granius Licinianus, Plutarch of Chaeronea, Appian of Alexandria) who discuss the period, stressing that each of them pointed to various aspects of the events from 78-77 BCE, and also revealing their mutual interdependencies and, predominantly, differences. Next, the author reconstructs the events related to the oration of $\mathrm{M}$. Aemilius Lepidus in $78 \mathrm{BCE}$, presenting the assumptions of his policy and possible political goals, drawing attention to the source that presents the history behind the speech in the most abundant manner, namely Historiae by C. Sallustius Crispus. Lepidus' speech is placed in the context of the period 78-77 BCE, when the Republic and its society struggled against the consequences of the civil war from $83-82$ BCE, and the rule by dictator L. Cornelius Sulla, which were so traumatic that Rome was unable to deal with them until the republican system collapsed. J. A. Rosenblitt reads the sources to reveal that violence in political life, exclusion of some social and political groups, and the exacerbating polarisation of the society were the result of Sulla's activities.

Part Three, entitled "Sallust and the Political Culture of Rome after Sulla," has been divided into four chapters. Here, J. A. Rosenblitt presents the political discourse in Rome of the first century BCE, which changed due to the events related to Sulla and his successors. The author claims that the transformation can be traced while relying on the works by Sallustius, principally including Historiae. In her opinion based on the analysis of Sallustius' work, just like any other dictator, Sulla intended to establish a stable rule that was not to be transformed, which stability was guaranteed by the implemented political and legal solutions (dominatio). She also believes that stabilisation could not rely on violence, manifested in the increasingly more ruthless language of the political discourse (the use of the term hostis in reference to political opponents, which used to refer to external enemies) and stronger polarisation of the Roman society. All these factors, together with the trauma of the events from the turn of the 80's and the 70's BCE, could form a model for further oratories by Roman politicians and leaders (including Pompey) in the first century BCE. A change was only to be brought about by the introduction of a new form of government (the principate) when the power was taken over by Augustus, which also meant a change to the political discourse, although even earlier, due to C. Julius Caesar, some limited actions were taken in this respect (clementia Caesaris).

The book by J. A. Rosenblitt is a thought-provoking voice in the discussion over the period of the 80's and the 70's of the first century BCE, and an interesting interpretation of Sallustius' Historiae, which is of major importance to the historical times discussed. One must also, however, point to some issues that could have been accentuated to a greater extent in the book. First of all, it seems that ruthlessness of the Roman policy was not simply a dubious 'achievement' of L. Cornelius Sulla's (crudelitas), but was of a much earlier provenience, dating back at least to the Gracchi brothers, and all the parties to the conflict in Rome were responsible for that. The author has also taken a challenge to build parallels between the political situation in Rome and contemporary states (p. 12), which may raise some doubts. This should not come as a great surprise to the Reader acquainted with prior works by the same author, who used to compare the situation in Rome under 
the rule of emperor Tiberius, relying on Tacitus' works, with English press releases about the situation in North Korea under the rule of Kim Jong Il! ${ }^{1}$

These are not, however, major drawbacks of the book. It seems that J. A. Rosenblitt, who relied her theses principally on the works by C. Sallustius Crispus, should give more attention to the moment when his historical works were written. This issue had been raised many times before by numerous researchers to Sallustius' works, who have also been referenced to in this book, ${ }^{2}$ but recently has become the object of discussion. ${ }^{3}$ This is because the works were written in the late 40's of the first century BCE at a very special moment in the Sallustius' life, as he had withdrawn from active political life, not perceiving hope for a change in Rome in the new situation (Caesar's death and the rule of the Second Triumvirate). Despite the fact that Sallustius deliberately remained outside the great politics, ${ }^{4}$ he attempted to comment on the contemporary events through the historical perspective, as a historian should. He described the events from the period of the Jugurthine War (Bellum Iugurthinum), the rule of Sulla and his successors in the period 78-67 BCE (the aforementioned Historiae), or the Catiline conspiracy (Bellum Catilinae), which nevertheless contained disguised criticism of the rule by the triumvirs: M. Antonius, Octavian, and M. Aemilius Lepidus. Although J. A. Rosenblitt perceives the ambiguity of various motifs and characters depicted in the works by Sallustius, also in Historiae, which are of major importance as a source for the history of the first decades of the first century BCE, this aspect could have been more exposed in her book.

Maciej Piegdoń (Jagiellonian University in Kraków)

J. A. Rosenblitt, Rome and North Korea: Totalitarian Questions, Greece \& Rome 59, 2012: 202-213.

2 Cf. also H. Appel, Animus liber. Kwestia obiektywizmu w pisarstwie historycznym Sallustiusza, Toruń 2004.

3 J. Gerrish, Sallust's Histories and Triumviral Historiography: Confronting the End of History, Routlege 2019.

4 Sallust. Bellum Catilinae 42: ... animus liber a spe metu partibus ... 